\title{
PEMBUATAN BATAS WILAYAH
}

(KELURAHAN BONTOTANGNGA KEC.TAMALATEA)

\author{
NAMA : ANNISA HASAN
}

NIM : 9173490210030

EMAIL : annisahasan3011@gmail.com

1. Bentuk Kegiatan

- Pembuatan batas wilayah

2. Lokasi

- Posko KKLP di Kelurahan bontotangnga

3. Hari Tanggal Dan Waktu

- Hari Jum'at 02 Oktober 2020 Pukul 14:00 Wita

4. Peserta Yang Dilibatkan

- Mahasiswa KKLP YAPTI JENEPONTO

5. Alasan Yang Diadakannya

- Setelah Observasi lapangan, kami melihat bahwa di beberapa lingkungan terdapat batas wilayah yang perlu di perbaharui.

6. Tujuan Dan Manfaat

- Kami mengadakan program kerja ini agar masyarakat lebih mudah mengetahui batas wilayah di daerah tersebut.

7. Deskripsi Kegiatan

- Proses pembuatan batas wilayah di lakukan selama beberapa hari, pembuatan batas wilayah ini dilakukan sebagai upaya memberikan kemudahan terhadap masyarakat dalam mengenali wilayah atau daerah tersebut. 